\title{
Традиции собирательства в фольклоре калмыков и тувинцев
}

\author{
Эльза П. Бакаева, Александра Т. Баянова, Виктория В. Куканова \\ Калмыцкий научный цеентр Российской академии наук, Российская Федерация
}

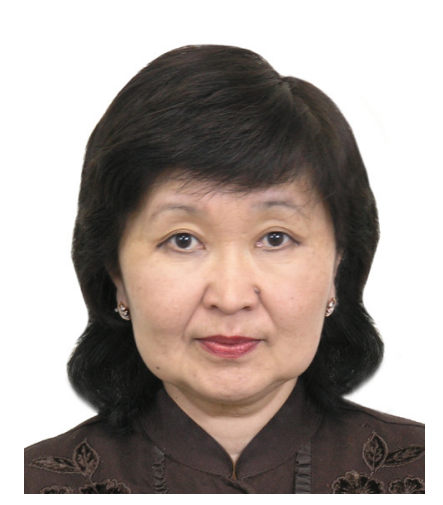

Настоящая работа посвящена особому виду хозяйствования некоторых народов Центральной Азии - собирательству. Предки тувинцев и ойратов относились в прошлом к «лесным» народам, поэтому в их культуре должны сохраниться те или иные традиции собирательства. Цель статьи - проанализировать на примере фольклора калмыков и тувинцев, как в фольклоре народов Центральной Азии сохраняются традиции такого древнего способа хозяйствования, как собирательство, а также выявить особенности традиционных представлений, связанных с мотивами собирательства. Материалом для анализа послужили фольклорные тексты разных жанров (в основном сказочные и эпические тексты). Это составляет новизну проведенного исследования, поскольку имеется большое количество этнографических материалов, содержащих в той или иной степени описание собирательства.

В результате анализа фольклорных материалов авторы пришли к выводу, что в фольклорных текстах минимально сохранились реликты собирательства, но, тем не менее, они все же там имеются. Тувинцы в большей степени их сохранили - в отличие от калмыков, которые не только сменили природную зону с тайги на степь, но и мигрировали на значительное расстояние от родины предков (из Центральной Азии в Нижнее Поволжье). Видимо, этот фактор и способствовал утрате упоминаний элементов древнего типа хозяйствования.

В тувинском фольклоре прослеживаются архаические традиции собирательства, которые в текстах связываются с примитивным состоянием общества и деятельностью персонажей - культурных героев. Собирательский труд связывается с женскими персонажами, и занятия сбором растений мужчинами порицаются либо осуществляются в особых ситуациях. В поздние времена собирательство было занятием беднейшего населения.

В калмыцких фольклорных текстах обнаруживается типологический сюжет о пребывании в архаическом состоянии, в изначальном мире, для которого характерны скудность пропитания, «травяная кибитка», отверженное состояние, непризнание обществом. Героям необходимо преодоление границы между этим изначальным миром и обществом, в котором занимаются скотоводством, чтобы обрести счастье и богатство.

Богатство в фольклорных текстах, содержащих материалы о примитивных занятиях охотой и собирательством, связывается с появлением одомашненных животных, что, несомненно, является влиянием ценностей культуры калмыков и тувинцев.

Ключевые слова: собирательство; традиция собирательства; лесные народы; калмыки; тувинцы; калмыцкий фольклор; тувинский фольклор; сравнительный анализ

Статья подготовлена по проекту «От палеогенетики до культурной антропологии: комплексное интердисциплинарное исследование традиций народов трансграничных регионов: миграции, межкультурное взаимодействие и картина мира» при поддержке мегагранта Правительства РФ (Соглашение о предоставлении из федерального бюджета грантов в форме субсидий в соответствии с пунктом 4 статьи 78.1 Бюджетного кодекса Российской Федерации № 075-15-2019-1879 от 3 декабря 2019 г.).

\section{Для цитирования:}

Бакаева Э. П., Баянова А. Т., Куканова В. В. Традиции собирательства в фольклоре калмыков и тувинцев // Новые исследования Тувы. 2020, № 4. С. 289-301. DOI: www. doi.org/10.25178/nit.2020.4.20

Бакаева Эльза Петровна - доктор исторических наук, ведущий научный сотрудник лаборатории междисциплинарных исследований востоковедного профиля Калмыцкого научного центра РАН. Адрес: 358000, Российская Федерация, г. Элиста, ул. им. И. К. Илишкина, д. 8. Тел.: +7 (84722) 3-55-06. Эл. адрес: ebakaeva@yandex.ru

Баянова Александра Тагировна - младший научный сотрудник лаборатории междисциплинарных исследований востоковедного профиля Калмыцкого научного центра РАН. Адрес: 358000, Российская Федерация, г. Элиста, ул. им. И. К. Илишкина, д. 8. Тел.: +7 (84722) 3-55-06. Эл. адрес: ale-bayanova@yandex.ru

Куканова Виктория Васильевна - кандидат филологических наук, исследователь лаборатории междисциплинарных исследований востоковедного профиля Калмыцкого научного центра РАН. Адрес: 358000, Российская Федерация, г. Элиста, ул. им. И. К. Илишкина, д. 8. Тел.: +7 (84722) 3-55-06. Эл. адрес: vika.kukanova@gmail.com 


\title{
The tradition of foraging in Kalmyk and Tuvan folklore
}

\author{
Elza P. Bakaeva, Alexandra T. Bayanova, Victoria V. Kukanova \\ Kalmyk Scientific Center, Russian Academy of Sciences, Russian Federation
}

This article is devoted to foraging as a type of economy specific for certain peoples of Central Asia. Ancestors of Tuvans and Oirats followed the "forest" type of economy, and their descendants must have preserved some of the foraging traditions. The authors aim to analyze the Kalmyk and Tuvan folklore for surviving traditions of foraging as an ancient type of Central Asian economy. The article also describes foraging-related details of traditional worldview. The study focuses on folklore texts of various genres, largely on fairy tales and epic. The ethnographic materials which contain descriptions of foraging are quite abundant.

The study helped the authors arrive at a conclusion that although the folklore texts show only a few traces of foraging, some do indeed survive. Tuvans have preserved more of them, while Kalmyks both changed their climatic zone (from taiga to the steppe) and migrated far away from their ancestral lands, from Central Asia to the Lower Volga. This is the factor which must have removed most of the mentions of the old type of economy.

Tuvan folklore features some of the archaic traditions of foraging which the texts link to primitive society and the cultural heroes of the folklore traditions. Foraging is usually associated with female characters, and gathering plants for men was a reproachable activity, allowed only under special circumstances. Later foraging became typical for the poorest part of the population.

Kalmyk folklore texts feature a plot of a staying in archaic conditions in the original world, with its typical features, such as the scarcity of food, the 'wagon of grass', the reprobate state, or lack of social recognition. Characters had to cross the border between the original world and the social world in order to take up cattle breeding to achieve welfare and happiness.

In the folklore texts containing information on primeval hunting and foraging, welfare is linked to the domestication of animals, which reveals the influence of the values of Kalmyk and Tuvan culture. study

Keywords: foraging; foraging tradition; "forest” economy; Kalmyks; Tuvans; Kalmyk folklore; Tuvan folklore; comparative

Financing

The reported study was funded by government grant in the form of federal budget subsidy aimed to support scientific research directed by the Leading Scientist - project name 'From Paleogenetics to Cultural Anthropology: Comprehensive Interdisciplinary Research of Peoples and Traditions of Cross-Border Regions - Migrations, Cross-Cultural Interactions and Worldviews'.

\section{For citation:}

Bakaeva E. P., Bayanova A. T. and Kukanova V. V. Traditsii sobiratel'stva v fol'klore kalmykov i tuvintsev [The tradition of foraging in Kalmyk and Tuvan folklore]. New Research of Tuva, 2020, no. 4, pp. 289-301. (In Russ.). DOI: www.doi. org/10.25178/nit.2020.4.20

BAKAEVA, Elza Petrovna, Doctor of History, Leading Research Fellow, Oriental Studies Interdisciplinary Research Laboratory, Kalmyk Scientific Center, Russian Academy of Sciences. Postal address: 8 Ilishkin St., 358000 Elista, Russian Federation. Tel.: +7 (84722) 3-55-06. E-mail: ebakaeva@yandex.ru

ORCID ID: 0000-0002-5188-1202

BAYANOVA, Aleksandra Tagirovna, Junior Research Fellow, Oriental Studies Interdisciplinary Research Laboratory, Kalmyk Scientific Center, Russian Academy of Sciences. Postal address: 8 Ilishkin St., 358000 Elista, Russian Federation. Tel.: +7 (84722) 3-55-06. E-mail: ale-bayanova@yandex.ru

ORCID ID: 0000-0002-5689-6454

KUKANOVA, Viktoria Vasilevna, Candidate of Philology, Leading Research Fellow, Oriental Studies Interdisciplinary Research Laboratory, Kalmyk Scientific Center, Russian Academy of Sciences. Postal address: 8 Ilishkin St., 358000 Elista, Russian Federation. Tel.: +7 (84722) 3-55-06. E-mail: vika.kukanova@gmail.com 


\section{Введение}

Тувинцы и ойраты, часть которых стала этническими предками калмыков, известны в истории Центральной Азии как народы, издавна занимавшиеся кочевым скотоводством. Этот хозяйственнокультурный тип являлся доминирующим у калмыков до 1920-х гг.; среди тувинцев кочевые традиции сохранялись и до середины ХХ в.

Как отмечал С. Ю. Неклюдов, «лесной» период и контакты с тюркскими племенами отражены в мифологии ойратов и калмыков в большей степени, чем у других монгольских народов (Неклюдов, 1988). Это мнение примечательно, ведь предки современных калмыков много веков назад освоили степные пространства. Фольклор других в прошлом относившихся к «лесным» народов, не менявших столь кардинально территории своего расселения, тем более сохранил связь с этим периодом.

Известно, что охота как тип хозяйства связана с традициями собирательства как присваивающего хозяйства. В культуре народов, относившихся в прошлом к «лесным», должны сохраняться традиции собирательства.

Цель статьи - проанализировать на примере фольклора калмыков и тувинцев, как в фольклоре народов Центральной Азии сохраняются традиции такого древнего способа хозяйствования, как собирательство, а также выявить особенности традиционных представлений, связанных с мотивами собирательства.

Для анализа привлечены фольклорные тексты, опубликованные в разных изданиях, сборниках (Калмыцкие богатырские сказки ..., 2017; Калмыцкие сказки, 1962ab; Калмыцкие сказки, 1978; Семь звезд ..., 2007; Хальмг туульс ..., 1974; Сказки народов Сибири, 1984; Сказки и предания ... , 1994; Тувинские героические ..., 1997; Тувинские народные ..., 1988, 1994ab). Этим и определяется новизна проведенного исследования. Также учитывались этнографические работы, свидетельства исследователей о традициях собирательства у калмыков и тувинцев.

\section{Из истории хозяйства тувинцев и ойратов}

В историографии имеются разные точки зрения по вопросу о датировке распространения кочевого скотоводства как хозяйственно-культурного типа в среде монголоязычных и тюркоязычных народов Центральной Азии. Так, на территории Алтая и приалтайских степей пастушеское скотоводство у оседлого населения, занимавшегося охотой и рыболовством, имело распространение во II - начале I тыс. до н. э., а интенсивное развитие скотоводства в кочевой форме, создавшее своеобразную культуру ранних кочевников Алтая, датируется периодом с VII в. до н. э. до I в н. э. (Потапов, 1953: 60). Как отмечает С. И. Вайнштейн, территория Тувы, расположенная в центре Азии, входила в «область формирования культур полукочевников и кочевников как аридной зоны, так и холодного пояса Земли, именно здесь был древний очаг взаимодействия хозяйственно-культурных типов кочевых скотоводов степей и охотников-оленеводов тайги, сохранившихся до середины XX в.» (Вайнштейн, 1991: 3).

Раннюю историю монгольских племен ученые связывают с более восточными (по отношению к современному ареалу расселения) территориями, где они занимались охотой и рыболовством, а также, возможно, земледелием (Кызласов, 1992: 129-130; Дашибалов, Рассадин, 2004; Дашибалов, 2005). По мнению Л. Р. Кызласова, монгольские племена начали миграцию на запад с движением киданей; на обширной территории до Дальнего Востока в это время прослеживалось влияние культур тюркоязычных степных народов (Кызласов, 1992: 129-130). В связи с вышеизложенным распространение кочевого скотоводства в среде монгольских народов исследователи датируют второй половиной I тыс. н. э.

Известно, что ученые выделяли среди монгольских народов в начале II тыс. н. э. «степных» и «лесных» монголов. К так называемым «лесным» народам относились в «дочингисову эпоху» и ойраты. Из источников известно, что «ойраты, прежде чем стать скотоводами, долгое время были охотникамизвероловами, но в то же время “не гнушались и рыболовством” (Санчиров, 2003: 204). Основываясь на данных археологических раскопок и их интерпретации, В. П. Санчиров, характеризуя материальную культуру ойратов XI-XIII вв., приходит к выводу, что различие в занятиях было обусловлено социальным расслоением, и если одни занимались скотоводством, то бедные слои занимались земледелием, скотоводством и домашними ремеслами (там же: 206), и только в последующий период ойраты «превратились в чистых кочевников. В конце XIV в. они уже обитают в Западной Монголии, где кочуют по Алтаю и прилегающим к нему степям и гористыми местностям. Экстенсивное скотоводство стало у них доминирующим средством существования, как и у восточных монголов» (там же: 207). Таким образом, предки современных калмыков относились к «лесным народам». 
Исторические условия сложения этнических групп, ставших основой современных тувинцев, обусловили наличие разных хозяйственных занятий среди этих народов, что было связано с территорией их расселения. Так, западные тувинцы - скотоводы, а в среде восточных тувинцев было распространено оленеводство, которое сочеталось с охотой.

Таким образом, часть «лесных» народов, расселяясь в степной части, переходила к кочевому скотоводству, другие - занимались хозяйством, в котором сохранялась значительная роль охоты.

\section{Традиции собирательства у тувинцев}

Л. П. Потапов, обращаясь к термину «лесные» народы, отмечает, что, хотя термин является признаком расселения в лесистой местности, но он не дает представления о хозяйственном и бытовом облике этих народов (Потапов, 1969: 80).

Рассматривая в этой связи Алтае-Саянско-Хангайское нагорье как особую историко-этнографическую область, ученый отмечает, что в ней были расселены народы «в пограничной географической зоне между глухой горной тайгой и горными степями и полупустынями» (там же: 81).

В начале XX в. большинство тувинских хозяйств имело полунатуральный характер. Наряду с преобладающим типом хозяйства сохранялись и традиции охоты и собирательства, что определялось природными условиями и отражалось в народных знаниях. Так, у тоджинских тувинцев-чооду зафиксированы названия месяцев, отражающих занятия охотой и собирательством: ыдалаар ай - охотничий месяц, когда охотятся с собаками (апрель), пестер ай - месяц копания кандыка (июнь), тостар ай - месяц сдирания бересты с берез для покрытия жилища (июль), айнаар ай - месяц копания сараны (август), кульбус ай-месяц охоты на козулю (самца, август), тииннер ай-месяц охоты на белку (октябрь), алдылаар ай - месяц охоты на соболя (октябрь); такой календарь не характерен для западных и юговосточных тувинцев (там же: 288-289). Названия этого типа имеют сходство с названиями такого типа календаря, зафиксированного у северо-восточных тувинцев-тоджинцев, хакасов, северных и южных алтайцев ${ }^{1}$, в котором названия месяцев имеют либо фенологическое значение (месяц кукования кукушки и т. п.), либо хозяйственное значение (время копания сараны, кандыка).

Как отмечает Л. П. Потапов, среди тувинцев «значение собирательства было чисто потребительским - пищевым и довольно ощутимым в пищевом балансе... Главнейшими дикими съедобными растениями в подтаежной и таежной зоне были корни пиона (Peonia anomala), клубни кандыка (Erythronium dens canis L.), луковицы сараны (Lilium marthagon) и др., в горностепных районах живородная гречишка (Polygonum vivipazum L.), семена которой шли для приготовления талкана, а корни (...мекир, мыйрак) - для приготовления своеобразной муки. Различные виды дикого лука и чеснока также имели широкое употребление. Продукты собирательства играли важную роль в начале весны, когда пищевые запасы были на исходе...» (Потапов, 1969: 88). Из дикоросов тувинцы использовали сарану, кандык, осоку, таволгу, бадан, кору деревьев, орехи хвойных деревьев, что запечатлено в фольклоре: «Травы осоки нарвав, отцу-матери питье он варил, коры насдирав, пищу готовил» (Тувинские народные сказки, 1994а: 127); «Пусть из таволги отрава не выйдет» (там же: 275), «Я свой бадан сварю, жажду старых моих отца-матери утолю, кору отварю, голод отца-матери утолю) (там же: 59).

В использовании тувинцами дикорастущих растений выделяются сарана и кандык, которые употреблялись в пищу, и растения, которые использовались для приготовления чая - бадан (Bergenia crassifolia), кипрей узколистный (из него готовили черлик шай), марьин корень или пион уклоняющийся (из которого готовили шеңне шай), болотник, кора лиственницы, плоды шиповника (Потапов, 1969: 201; Шараева, Айыжы, 2019: 153).

Различие в хозяйственно-культурном типе у представителей разных групп одного этноса определяло привязанность к привычному образу жизни, что способствовало появлению представлений о преимуществах своего образа жизни. Л. П. Потапов приводит сведения Ф. Я. Кона об имевших место случаях, когда девушки из семей скотоводов-охотников, выданные замуж за таежных охотниковоленеводов, возвращались в родную семью (Потапов, 1969: 90), и данные Рашид-ад-Дина о средневековых таежных охотниках («лесных урянхатах»), среди которых возможность быть отданной замуж за скотовода представлялась своеобразной угрозой, настолько кочевой быт представлялся чужеродным: «считали “большим пороком пастьбу баранов...” (цит. по: там же: 90).

${ }^{1}$ В алтайском календаре зафиксированы подобные наименования месяцев: бессай - время сбора кандыка

(май), ак-сип-ай - время сбора сараны (июнь). 
Традиции архаичного типа хозяйствования, как можно предположить, могут обнаруживаться в образцах фольклорных жанров, отражающих древнейшие представления о мире. Так, в тувинском сказании «Балджын Хээр» повествование начинается с восхваления богатства Алтая - сакрального центра для народов, расселявшихся в его регионе. Среди богатств Алтая перечисляются молодые люди обоих полов (что связано с обеспечением богатства людских ресурсов), мудрые старейшины (что свидетельствует о продолжительности жизни в прекрасном ареале), кони (коневодство как способ хозяйствования характерно для древних тюрок), но прежде всего - самые востребованные из дикорастущих растений:

«У тебя кандык и саранка есть, мой Алтай,

У тебя юноши и девушки есть, мой Алтай,

У тебя иноходцы и скакуны есть, мой Алтай,

У тебя разумные и мудрые есть, мой Алтай!» (Сказки и предания ..., 1994: 296).

Упоминание в зачине сказания и начале стихотворного восхваления кандыка и сараны (саранки) как даров Алтая отражает архаические традиции тувинцев, связанные со значением собирательства; хотя в целом стихотворное восхваление отражает коневодческий характер хозяйства народа, в среде которого бытовало данное сказание, названное по имени коня главного героя. В сказании точно указывается гендерное распределение хозяйственных занятий героев: занятия мужчины - охота на диких овец и оленей, занятие женщины, кроме домашней работы, - сбор даров природы (кореньев).

Герой Балгынак скачет «к пестрым вершинам своего Алтая за добычей», его сестру Алдын Гээш посылают «за кандыком и саранкой», чему, очевидно, отводится второстепенное значение. Но весь сюжет закручивается после действия, служащего инициативным - сокрытию хозяином мрачных ущелий Узээнэком от Алдын Гээш ее сумы с собранными корешками:

«Жена его послала свою золовку Алдын Гээш

За кандыком и саранкой.

Хозяин мрачных ущелий

Благородный великий Узээнэк

Был тронут красотой нежной девушки,

Увидев ее, он смутился.

Не смог удержаться

И спрятал ее суму с корешками» (там же: 297).

Следствием сокрытия хозяином ущелий корешков (то есть собранного для пропитания) становятся изгнание Алдын Гээш из родного жилища и ее страдания, прежде всего от голода («удрученная и грустная, бесцельно бродила среди пестрых вершин, одолеваемая голодом и жаждой»). В итоге она «отдается хозяину ущелий», т. е. погибает.

Эпический материал дает основание для выделения архаического типа хозяйствования у тувинцев, который в текстах называется «жить пищей земли».

В тувинском героическом сказании «Боктуг-Кириш, Бора-Шэлэй» рожденные у одиноких в поколении престарелых супругов сын Боктуг и дочь Бора однажды оказываются у разоренного очага. Начало жизни героев в новом мире связывается с архаическими практиками собирательства, дарующего жизнеобеспечивающий продукт:

«[Корни] ургене, кичигене, кандык и саранку, ягоды и орехи давай будем есть ... стали жить пищей земли, чай из [травы-]шене варили и пили - [Так], оказалось, зажили. Так вот [живя], рыб-пескарей, мышей-сусликов убивать и кормиться ими решили...» (Тувинские героические ..., 1997: 307).

Здесь важно отметить, что инициатива «возвращения» к собирательской традиции исходит от девушки, что вновь подтверждает древнюю традицию занятий собирательством женщинами. И лишь затем герои сказания, «осваивающие мир заново», то есть выступающие как культурные герои, осваивают рыболовство и начинают постепенно охотиться, после чего следует сюжет одомашнивания героями жеребенка - метафорического зарождения коневодства (там же: 309).

Примечательно в тексте сказания сопоставление людей и животного, введение жеребенка в мир людей, в культурный мир - культурными героями, сопровождающееся вкушением пищи, потребляе- 
мой людьми и «подходящей» для одомашниваемого животного - это растительная пища и чай из шене (марьиного корня):
«Что пили - тем напоили,
Что ели - тем накормили,
И когда расчесали, пригладили, -
От них не отстает,
Следом за ними бежит» (там же: 309).

Как свидетельствуют тексты тувинских сказаний, собирательские традиции были характерны для эпохи культурных героев, «начала времен». Там же мы находим и примитивное собирательство, последующее освоение рыболовства и гендерное распределение хозяйственных занятий между мужчинами и женщинами.

Так, в одной из тувинских сказок Курбусту-хан отправляет зятьев в дальние страны за золотым маралом, на что младший из них, Хеверик, объявляет: «Коня у меня нет, ехать мне не на чем. Пойду мальков ловить да сарану собирать» (Тувинские народные сказки, 1988: 48). Супруга же его, Золотая царевна, печалится после слов мужа - «стыдно ей стало за своего мужа» (там же). Для мужчины это постыдный поступок. В аспекте же рассматриваемой нами темы значимым является следующее: герой обращается к примитивному способу хозяйствования, а также собирается заняться не мужским делом.

В сказочном сюжете уход в лес и объявление о том, что основным занятием будет являться рыболовство и собирательство, может быть рассмотрен как уход в иное состояние, иной мир. Так, в другой тувинской сказке герой Ховен-Тажы:

«переехал семь перевалов, семь рек и попал в чудесный край. Возвышается в серебряной шапке

высокогорная тайга. Текут с этой горы две холодные прозрачные реки. Берега их покрыты нежной зеленой травой и сладкой ягодой, а в воде резвится рыба» (там же: 70).

Указание на удаленность в вышеприведенном тексте, как и числовая символика семерки, которая в культуре ряда тюрко-монгольских народов указывает на достаточность, могут быть рассмотрены как свидетельство пребывания героя в ином состоянии, ином мире. Об этом свидетельствует и его встреча с воскресшей девушкой Чечен-Ноган (букв. 'Вечнозеленая’), «рожденной в цветке», которую он обнаруживает на вершине высокогорной тайги в белом атласном шатре (там же).

В тувинской богатырской сказке «Хайындырынмай Багай-оол» говорится, что счастье и удача героя Багай-оолу содержатся в доставшемся от родителей его одеянии, которое он носит «от рождения матерью». Наряд включает одеяние-кольчугу и золоченый убор ова[дай] (Тувинские народные сказки, 1994а: 73). Герой жертвует ими во благо сохранения жизни родителям, при этом теряя свою удачу. «И с той поры Хайындырынмай Багай-оолу и его отцу-матери старым туго-худо пришлось: оказалось, в одежде, в какой он ходил, и были [его] волшебства-чудеса, счастье удача» (там же: 75). Результат утраты участья-удачи понимается как попадание в архаическое состояние, когда единственным пропитанием являются продукты собирательства: «И стала чаем, что днем они пили, простая трава, а чаем, что ночью пили - [деревьев] кора» (там же).

С развитием хозяйственного типа собирательские традиции занимали все меньшую роль в тувинском обществе, что отразилось и в фольклоре, в котором собирательство увязывается с ранними временами. Недаром в одной из тувинских сказок заяц, сознаваясь в грехах, говорит: «Кроме того, что питался травой-муравой, корою деревьев да пил родниковую воду, других прегрешений я не совершал» (там же: 205).

В тувинском фольклоре сохранился также сюжет об орудии, которое использовалось для сбора кореньев, которое выступает в сказках как орудие культурного героя. В одном из вариантов сказки «АгСагыш и Кара-Сагыш» братья живут подаянием, затем один предает другого, и Ак-Сагыш, оставшийся без коня и брата, приходит к верховьям реки Кара-Суг, где, спрятавшись в чуме из конских голов и коры, оказался свидетелем разговора медведя, волка, лисицы и кабана. При этом каждый из зверей похваляется своей добычей: лиса наловила много сусликов, волк полакомился скотом Караты-хана, медведь добыл много кедровых орехов, а кабан накопал много сараны при помощи особой серебряной палки (Сказки народов Сибири, 1984: 31). Это серебряной палке в реальной жизни тувинцев соответствует специальное приспособление - озук. По сути, это палка-копалка. Сезон добывания сараны был для тувинцев горячей порой. На него снаряжались всей семьей. По сведениям П. Е. Островских, тувинцы заготовливали по нескольку пудов сараны (Островских, 1898). 
В «первоначальные времена» также действуют герои богатырской сказки «Хойындырынмай Багайоол» (Тувинские народные сказки, 1994а: 51). Значимость сараны как одного из основных продуктов собирательства отражена в имени женского персонажа, старухи Сарадай-в-саране (тув. сараңда Сарадай), основным занятием которой, как можно понять, являлось собирание сараны. Имя ее супруга, старика Оледея-в-осоке (тув. өлеңде Өледей), созвучно и ойратскому этнониму олет (оледей), однако восходит, видимо, к названию в тувинском языке осоки. Имя персонажа указывает на использование осоки в пищу тувинцами, но также может косвенно указывать на его занятия рыболовством, поскольку осока произрастает по берегам озер и рек, прудов (хотя некоторые ее виды и встречаются в степях).

Фольклорная традиция отражает также реалии хозяйства восточных тувинцев-тоджинцев, у которых собирательством обычно занимались старики, женщины и дети. Летом в тайге они собирали луковицы и корни диких растений, заготовляли их на зиму: «...Сарану копают с начала июля по ноябрь. Что особенно важно, женщину у оленеводов называли айнаар кижи - “человек, собирающий сарану” (Прокофьева, 2011: 336).

Значимость сараны (саранки) и кандыка в собирательских традициях тувинцев связана с распространенностью (произрастанием) этих растений в южной Сибири и их питательными свойствами. Так, известны пищевые свойства сараны, которую употребляют в сыром (с чаем), вареном (в том числе в виде кашеобразного супа айлыг быдаа из смолотой муки из сушеных луковиц), жареном, сушеном, печеном виде, а также в народной медицине. Подобным же образом используются и луковицы кандыка сибирского. Ученые описывают два основных способа сушки сараны для заготовки на зиму ${ }^{1}$ и приводят виды дикорастущих растений, которые составляли растительную пищу тувинцев-оленеводов: урун-ай (белая или мелкая сарана, Lilium Marthagon), кара-ай (крупная, темноватого цвета сарана, Polygonium viviparum), мыйрак ((клубни гречихи, Polygonium viviparum), шеңңне (марьин корень, Paeonia anomala), кандык (собачий зуб, Eritronium dens canis), черлик-шай (Geranium sylvaticum²) и др. (Ондар, 2018: 13).

Содержательные сведения об использовании дикорастущих растений в быту тувинцев приводятся учеными при анализе типов питания тувинцев. С. И. Вайнштейн выделяет два пищевых комплекса:

- «западнотувинский» (скотоводческий) пищевой комплекс базировался на продуктах кочевого скотоводческого хозяйства, сочетавшегося с земледелием. Основой питания значительную часть года служили молочная и в меньшей мере мясная и растительная пища, а также в небольшом количестве дикорастущие. Рыба употреблялась лишь беднейшими. Подспорьем было мясо диких животных, добытых на охоте. Использовались и продукты земледелия. Определенную роль играло также собирательство (Вайнштейн, 1991: 117);

- «восточнотувинский» (охотничье-оленеводческий) комплекс, для которого характерно «питание в течение всего года преимущественно мясом диких копытных и растительной пищей, приготовленной главным образом из дикорастущих, в меньшей мере - продуктами из оленьего молока и рыбой (с весны до осени). Домашних оленей забивали редко, сохраняя их прежде всего как транспортное средство» (там же: 118-119).

Пищевой комплекс, который сохранялся и в XX в. у восточных тувинцев, как отмечал С. И. Вайнштейн, в основных чертах восходил к древним традициям питания дооленеводческого населения пеших охотников и рыболовов горной тайги (там же: 119).

Таким образом, в тувинском фольклоре прослеживаются архаические традиции собирательства, которые в текстах связываются с примитивным состоянием общества (соответственно прослеживаются представления о преимуществах более развитого типа хозяйствования) и деятельностью персонажа, отличающегося чертами, сходными с чертами культурного героя. Собирательский труд связывается с женскими персонажами, и занятие сбором растений мужчинами порицается либо осуществляется в особых ситуациях. В поздние времена собирательство было занятием беднейшего населения.

\footnotetext{
${ }^{1}$ Первый способ: «луковицы мелко нарезали и сушили в течение дня на солнце, разложив на полосах бересты или в берестяном корыте». Второй способ, который применяли реже: «луковицы высушивали на специальном сооружении - аърга, под которым близ чума разводили небольшой костер. Если шел дождь, то сушили над очагом в чуме» (Ондар, 2018: 13-14).

${ }^{2}$ В работе А. У. Ондар дается это латинское название, обозначающее герань лесную. В статье Т. И. Шараевой и Е. В. Айыжы отмечается, что название черлик-шай переводится буквально «дикий чай», его варят из кипрея узколистого (иван-чая), а также даны сведения о других видах чая (Шараева, Айыжы, 2019: 145).
} 


\section{Традиции собирательства у калмыков}

Собирательство у калмыков мало изучено, так как основное внимание уделялось исследованию традиционных видов хозяйствования - скотоводству и земледелию. По утверждению У. Э. Эрдниева, растительная пища «не играла существенной роли в питании калмыков» (Эрдниев, 1970: 172). Большую часть времени женщины занимались уходом за скотом, переработкой продуктов животноводства.

В пищевом комплексе калмыков, у которых до начала XX в. основным занятием являлось кочевое скотоводство, также использовались (в основном в зимнее время) дикорастущие растения: дикий лук, осотняк, дикое просо, корень осоки, дикий орех и водяной орех. Собирательство этих растений было освоено калмыками в природных условиях Прикаспия (Калмыки, 2010: 199). Но в целом система питания оставалась характерной для скотоводов. Недостаток растительной пищи в рационе порой приводил к развитию таких болезней, как цинга и рахит (там же).

В числе пищевых предпочтений особое место в калмыцкой кухне занимал чай.Но так как кирпичный чай привозили в калмыцкие улусы из Китая, он был довольно дорогим напитком, и беднейшие слои населения употребляли его заменители - дикорастущие растения: хургн чикн - 'конский щавель' (Rumex acutus), бөөлжрльн - 'ежевика' (Rubus fruticosus). Эти коренья, писал П. И. Небольсин, «калмыки, не тратясь излишне на покупку кирпичного чая, собирают летом» (Небольсин, 1852: 49). Для заваривания чая использовали также собранную в степи «на тощих местах траву малого солодкового дерева с гладкими листьями» (Паллас, 1773: 472). Как пишет В. Н. Корниевский, за недостатком средств калмыкам приходилось добавлять эти травы в чай, которые отчасти заменяли заварку: «тут уже всякая труха годится... все это добрая хозяйка высушит, да и сыплет не жалеючи в котелок, благо - не купленное» (Корниевский, 2017: 83).

Повсеместно калмыцкие женщины собирали суркул - ‘дикое просо’ в специальные кожаные мешки, после выколачивания палками зерна поджаривали, смешивали с бараньим жиром или маслом, сбитым из коровьего молока, и употребляли в пищу либо с маслом или бараньим салом, или вместе с сушеным сыром шүүрмг, либо заваривая будан (кашеобразный суп) (Небольсин, 1852: 50).

Калмыки, поселившиеся в Мочагах, собирали водяной орех (чилим, Trapa natans) и дикий («свиной») орех, называемый по-калмыцки бодмонцк. Их выкапывали на займищах, сушили и готовили на огне. На займищах в августе-сентябре также собирали корешки алцнхут - 'осоки' (Сiperus), из которых готовили лакомство для детей. После растирания в ступе и смешивания с кирпичным чаем из него готовили тесто и запекали его в горячей золе: «...кушанье это так вкусно, что от него ни один калмык не откажется» (там же).

Использовали калмыки в еду и собранный в степи жзһамул - ‘дикий лук', который употребляли с мясом в супе. В одной из калмыцких загадок упоминается это растение: Әәдрхнә цзаад бийд әрә hолта жаһамул - 'На той стороне Астрахани дикий лук с маленьким зеленым стебельком’ (Отгадка: хоолын күүкн - ‘язычок мягкого неба') (Калмыцко-русский словарь, 1977: 223). Жаһамул - ‘дикий лук’ опосредованно отражен в калмыцкой народной песне «Жаһамул үстә» ('С прической, похожей на дикий лук’): «Жомбан Манж цокдг билә, Жаһамл үстәнь биилдг билә» (букв. 'Джомбан Манджи играл на домбре, а тот, с прической в виде пучка (похожего на жаһамул), танцевал’).

Перечисленные сведения относятся к пребыванию калмыков в приволжских степях. Необходимо учитывать также, что в прошлом для культуры этнических предков калмыков - ойратов - были характерны традиции, свойственные «лесным» народам. Но хозяйственный тип, имевший распространение у ойратов, был сходным со скотоводческим тувинским, в котором в меньшей степени сохранялись традиции собирательства.

Во время путешествия в 1876-1877 гг. Г. Н. Потанин отмечал, что монголы употребляли зерна диких растений: кумарчика песчаного или колючего (Agriophyllum arenarium), мари остистой (Теlохуs aristata), которую в народе называют перекати-поле. В горах добывали корень горца живородящего (Polygonum viviparum), который, по свидетельству Г. Н. Потанина, монголы называли мякир, он похож на лещинный орех с ароматом розовых лепестков. Корень мякира был покрыт тонкими волосовидными корешочками, их долго вываривали, вытаскивали из котла и промывали «до семи раз в холодной воде» и протирали, чтобы уменьшить количество волосков, затем продолжали варку в молоке. По вкусу он напоминал горошек или кукурузу и служил приправой к мясному супу (Потанин, 1881: 113). Калмыки тоже использовали эти растения в пищу.

У калмыков факт использования зерен кумарчика запечатлен в фольклоре. В легенде «Брат орла» повествуется о том, как калмык гнал отару овец и не мог найти ни травинки для скота. Вот и последняя 
овца пала от голода, сам Бадма впал в забытье. И видится ему птица, говорящая ему человеческим голосом: «Там, за песчаной грядой.... есть земля с пышными травами...Ты собирай траву кумарчик и выбивай из нее семена. Толки зерна и вари кашу, пышки пеки. Кумарчик - трава вкуснее риса» (Семь звезд ..., 2007: 233-234). Это и спасло его от голода.

В целом, как мы уже упоминали, сведения о собирательских традициях в калмыцком фольклоре довольно редки. Но, поскольку, как и у других народов, сбор трав для лечения был одним из традиционных видов собирательства и с давних пор травы в виде отваров и различных снадобий использовались в лечении болезней, в калмыцких сказках зачастую встречаются именно такие свидетельства. Так, в сказке «Эркә Билдр залу» главный герой падает в пропасть. Придя в сознание, он видит, как к нему прибегает мышь. «Когда человек слаб, то и мышь чувствует свое превосходство», - подумал мужчина и ударяет мышку. И вдруг он видит, как раненая мышь оживляет себя: приносит траву и съедает ее. По примеру мыши Эркя Билдер тоже использует траву и оживает (Хальмг туульс, 1974: 24). Об этой чудесной траве упоминается и в сказке «Субсутай». В ней герой, также глядя на поведение мыши, исцеляющей себя с помощью травы, решает испробовать это же средство, чтобы воскресить убитых. Он нарвал траву, сварил в котле и стал вливать отвар в рот каждому мертвецу (Калмыцкие сказки, 1962b: 15).

О сборе трав для исцеления упоминается и в калмыцкой легенде «Нугра»: «С самого раннего утра, когда степь оглашается звонкой трелью жаворонков, и до позднего вечера ходили они [старая Булгун и ее дочь] по степи, собирая целебные травы... До поздней зари колдовала она над кипящим котлом, готовила какие-то снадобья, настаивала травы, бормоча что-то, ей только известное» (Семь звезд ... , 2007: 223).

Для лечения зрения использовали калмыки терн (Prunus spinosa) - небольшой колючий кустарник, растущий густыми зарослями в степи. Так, в сказке «Богатырь Шарада» главный герой собирает терн, растирает листья его и прикладывает к глазам для того, чтобы лучше видеть (Калмыцкие сказки, 1962а: 168).

Вместе с тем в фольклоре также можно найти отдельные свидетельства, относящиеся к древним занятиям их предков собирательством и представлениям об этом архаическом занятии.

В сказке «Три брата» прослеживаются разнообразные действия, в ней содержатся элементы богатырской сказки, волшебной и бытовой, а наличие способности жеребиться трижды в день у действующего персонажа - единственной у старика и старухи бурой кобылицы - является характерным для мифологических сюжетов. В сказке спасенная желтой собакой от нерадивых хозяев кобылица бежит непонятно куда из места прежнего пребывания, спасает трех новорожденных мальчиков в стране грозного хана и попадает в большой дремучий лес, где строит себе жилье из травы и выкармливает детей своим молоком, одаривает мальчиков табунами лошадей и лишь затем превращается в облако, кричит по-лебединому и улетает. Последующие действия сюжета посвящены поискам младшим из трех сыновей кобылицы - Кокодей Мудрым - жен для себя и братьев, зависти старших братьев и расправе их с ним. Сюжетная линия развивается следующим образом: братья ставят Кокодэ Мудрому «травяную кибитку» и оставляют его, лишившегося ног из-за их козней, там, а сами откочевывают со скотом (Калмыцкие сказки, 1978: 90). Затем Кокодэ Мудрый встречает слепого и безрукого, они поселяются вместе, добывают себе жену - дочь Хормусты, занимаются все вместе охотой, спасают дочь Хормусты от мусов и излечиваются, а после Кокодэ Мудрый возвращает себе суженую и хозяйство (там же: 89-102). «Травяная кибитка» упоминается и в калмыцкой сказке «Старик сам в четверть, а борода в три четверти», в тексте которой говорится, что старики живут в «травяной кибитке» (там же: 47).

Образ так называемой «травяной кибитки» сопровождает тему бедного и примитивного существования, заброшенности.

В калмыцкой богатырской сказке «Вороного с лысиной коня имеющий Хадыр Хара Авги Хан Сенаки» богатырь Хан Сенаки одерживает победу и женится на суженой, но остается в облике паршивца, а супруга его уговаривает обрести его облик (Калмыцкие богатырские сказки ... , 2017: 419). Примечательно, что пребывание их в таком состоянии приводит к изгнанию из общества и сопровождается ограниченностью пищи, отсутствием молока для варки чая и иных продуктов для еды: «два старших зятя явились рассерженные. - Стыдно перед людьми, в безводную степь, в безлюдную пустыню отвезите их и оставьте, избавьте нас от них, - сказали. В безлюдную пустыню, в безводную степь отвезли их, оставили. Так они и жили там. Девушка всё твердила: - Почему в таком облике 
пребываете? Примите свой прежний облик. - А в каком облике я пребываю, это мой истинный облик, и родители у меня такие... - отвечал он ей» (там же: 419). Превращение паршивого мальчика обратно в богатыря происходит после вкушения появившейся волшебным образом пищи, так как «истинному облику» паршивца, характеризующему его пребывание в изначальном состоянии, присущи бедность и скудость в питании:

«Свари немного чая. - Из чего сварить? Чтобы сварить, чая нет ведь у нас, чтобы испечь, муки ведь нет у нас, - ответила [жена]. - Хотя бы воду вскипяти, - сказал он. - Вы же не больны, как можно воду пить? - Пусть не кипяток, и тёплая сгодится» (там же: 421).

Типологически сходный мотив изоляции и питании продуктами собирательства присутствует и в калмыцкой сказке «Долан һуульһнч» ('Семь попрошаек'). Калмыцкий хан спорит с ханом Гаруди и, не найдя достойного жениха для дочери, поселяет ее в изоляции «за морем». И хотя в тексте говорится, что хан «поставил дом, обеспечил едой и держал ту свою дочь, пока не исполнилось ей пятнадцать-шестнадцать лет», но указывается, что «никто не присматривал за ней». Предсказание Бурхана Багши о том, что девушка выйдет замуж за одного из семи попрошаек, сбывается. Девушка жила в безлюдном месте, где с помощью хана Гаруди оказался юноша - один из семи попрошаек. Он женился на девушке (Хальмг туульс, 1974: 199-201).

Попрошайничество в калмыцкой сказке косвенно сопоставляется с собирательством: именно им занимаются семь попрошаек, когда один из них попадается Гаруди. Пребывание за морем в безлюдном месте можно сопоставить с пребыванием героев сказки в изначальном мире, а наличие парши у юноши на голове - с мифологическим образом тархи-паршивца, который появляется после инициации в мире.

Таким образом, в калмыцких фольклорных текстах обнаруживается типологический сюжет о пребывании в архаическом состоянии, в изначальном мире, для которого характерны скудность пропитания, «травяная кибитка», отверженное состояние, непризнание обществом - и герои в этом мире добывают пропитание, лишь затем обретая хозяйство как у других людей. Преодоление границы между этим миром и обществом, в котором занимаются скотоводством, в сказках завершается утверждением об обретении счастья и богатства героями.

\section{Заключение}

Анализ фольклорных текстов тувинцев и калмыков показывает наличие общих типологически сходных черт в отражении традиций собирательства. Это прежде всего описания, связанные с пребыванием в особом, изначальном мире, который характеризуется как мир, не принимаемый основным сообществом, как чужеродный в силу своей архаичности и примитивности, а также понимаемый как мир бедности. Богатство в фольклорных текстах, содержащих материалы о примитивных занятиях охотой и собирательством, связывается с появлением одомашненных животных, что, несомненно, является влиянием ценностей культуры калмыков и тувинцев, образцы фольклора которого рассмотрены в статье.

Как и в тувинской культуре, у калмыков исследователями зафиксированы представления о преимуществе образа жизни групп с различными хозяйственно-культурными типами и их вариантами. Так, широко известно свидетельство У. Д. Душана (Душан, 1973: 45), о котором Т. И. Шараева пишет: «У. Д. Душаном был зафиксирован в начале XX века образец фольклора, в котором мать выходящей замуж девушки переживает не только об ее будущей жизни, но и питании дочери в новой семье с непривычным укладом: “Милая моя, ты выросшая, питаясь привычным тебе мясом белуги и осетра, ты будешь теперь питаться этим невкусным, водянистым мясом барана. Ты, привыкшая сидеть на корме лодки и направлять ее рулем куда захочешь, теперь будешь управлять головой двухмачтового (верблюда)"» (Шараева, 2019: 144). Такая привязанность к собственному образу жизни, присущая даже для разных групп одного народа со сходным типом хозяйства, объясняет устойчивость традиций и неприятие иных, воспринимаемых как чужеродные, традиций. В соответствии с типологическим противопоставлением «своего» и «чужого» объясняется и сложившееся на протяжении веков в фольклоре представление об архаичности, примитивности и бедности людей, занимающихся охотой и собирательством.

В целом можно отметить, что в калмыцких текстах несравнимо в меньшей степени, чем в тувинских, отражены традиции собирательства. Кроме того, нам не встретились в них упоминания кон- 
кретных продуктов собирательства - в отличие от сараны и кандыка, которые являлись в прошлом основными дикоросами, использовавшимися «лесными» народами южной Сибири и которые зафиксированы в целом ряде тувинских текстов.

Исследование фольклорных текстов в избранном нами аспекте перспективно: во-первых, необходимо привлечь к анализу более широкий спектр текстов и источников, во-вторых, важны отдельные исследования, посвященные теме народных знаний и различных традиций в тувинском и калмыцком фольклоре.

\section{СПИСОК ЛИТЕРАТУРЫ}

Вайнштейн, С. И. (1991) Мир кочевников центра Азии. М. : Наука. 296 с.

Дашибалов, Б. Б., Рассадин, В. И. (2004) Откуда вышли предки монголов? // Восточная коллекция. Зима. № 4 (19). С. 34-41.

Дашибалов, Б. Б. (2005) На монголо-тюркском пограничье (Этнокультурные процессы в Юго-Восточной Сибири в средние века). Улан-Удэ : Изд-во БНЦ СО РАН. 202 с.

Душан, У. Д. (1973) Историко-этнографические заметки об Эркетеневском улусе Калмыцкой АССР // Этнографические вести. № 3 / ред. Н. Ш. Ташнинов. Элиста : Калмыцкий НИИЯЛИ. 229 с. С. 31-107.

Калмыки (2010) / отв. ред. Э. П. Бакаева, Н. Л. Жуковская. М. : Наука. 567 с.

Калмыцкие богатырские сказки = Хальмг баатрлг туульс (2017) / подг. текстов, перелож., пер. Б. Б. Манджиевой, Т. А. Михалевой, Ц. Б. Селеевой. М. : Калмыцкий науч. центр РАН. 560 с.

Калмыцкие сказки (1962а) / под ред. И. К. Илишкина и У. У. Очирова. Элиста : Калмгосиздат. 331 с.

Калмыцкие сказки (1962b) / сост. и предисл. Б. Джибинова. Элиста : Калмгосиздат. 183 с.

Калмыцкие сказки (1978) / пер. с калм. Элиста : Калм. кн. изд-во. 148 с.

Калмыцко-русский словарь (1977) / под ред. Б. Д. Муниева. М. : Русский язык. 768 с.

Корниевский, В. Н. (2017) Калмыки Донской области, Астраханской и Ставропольской губернии. Элиста : КалмНЦ РАН. 85 с.

Кызласов, Л. Р. (1992) Очерки по истории Сибири и Центральной Азии. Красноярск : Изд-во Красноярского университета. 224 с.

Небольсин, П. И. (1852) Очерки быта калмыков Хошоутовского улуса. СПб. : Тип. К. Крайя. 192 с.

Неклюдов, С. Ю. (1988) Ойрат-калмыцкая мифология // Мифы народов мира : в 2 т. / глав. ред. С. А. Токарев. М. : Советская энциклопедия. Т. 2. 671 с. С. 247-248.

Ондар, А. У. (2018) Система питания тувинцев-тоджинцев // Актуальные проблемы исследования этноэкологических и этнокультурных традиций народов Саяно-Алтая. Материалы V-ой международной научнопрактической конференции молодых ученых, аспирантов и студентов / отв. ред. У. В. Ондар. Кызыл : Тувинский госуниверситет. 235 с. С. $12-15$.

Островских, П. Е. (1898) Краткий отчет о поездке в Тоджинский хошун Урянхайской земли // Известия ИРГО. T. XXXIV. Вып. IV. C. 424-432. 455 c.

Паллас, П.-С. (1773) Путешествие по разным провинциям Российской империи. Ч. 1. СПб. : Имп. Академии наук.

Потанин, Г. Н. (1881) Очерки Северо-Западной Монголии. Вып. 2. Материалы этнографические. СПб. : Тип. В. Киршбаума. 182, 87 с.

Потапов, Л. П. (1953) Очерки по истории алтайцев. М. ; Л. : Изд-во АН СССР. 445 с.

Потапов, Л. П. (1969) Очерки народного быта тувинцев. М. : Наука. 402 с.

Прокофьева, Е. Д. (2011) Процесс национальной консолидации тувинцев. СПб. : Наука. 535 с.

Санчиров, В. П. (2003) О материальной культуре ойратов XIII-XVII веков // Монголоведение. № 2 (1). С. $203-210$.

Семь звезд: калмыцкие легенды и предания (2007) / сост. Д. Э. Басаев. 2-е изд.Элиста : Калм. кн. изд-во. 415 с.

Сказки и предания алтайских тувинцев (1994) / собраны Э. Таубе. М. : Издательская фирма «Восточная литература» РАН. 382 с.

Сказки народов Сибири (1984) / перев. А. Л. Гарф и др. Новосибирск: Западно-Сибирское книжное издательство. 43 с.

Тувинские героические сказания. Хунан-Кара. Боктуг-Кириш, Бора-Шэлэй (1997) / сост. С. В. Орус-оол. Новосибирск: Наука. 584 с.

Тувинские народные сказки (1988) / пересказ и обраб. М. Хадаханэ. М. : Детская литература. 111 с. 
Тувинские народные сказки (1994а) / сост. 3. Б. Самдан. Новосибирск : Наука. 460 с.

Тувинские народные сказки (1994b) / отв. ред. В. М. Гацак. Новосибирск : Наука. 460 с.

Хальмг туульс [Калмыцкие сказки] (1974) / Барт белдснь Б. Б. Оконов, Е. Д. Мучкинова. Элиста : КНИИЯЛИ. 4-гч боть. 274 с. (На калм. яз.).

Шараева, Т. И. (2019) «И откуда Ваши сваты?» (реалии и ментальные образы пространства в свадебном обряде калмыков) // Новые исследования Тувы. № 3. 135-148. DOI: https://www.doi.org/10.25178/nit.2019.3.11

Шараева, Т. И., Айыжы, Е. В. (2019) Чай в традиционной культуре калмыков и тувинцев // Новые исследования Тувы. № 4. С. 140-153. DOI: https://www.doi.org/10.25178/nit.2019.4.12

Эрдниев, У. Э. (1970) Калмыки (конец XIX - начало XX в.): историко-этнографиеские очерки. Элиста : Калмиздат. 307 с.

Дата поступления: 12.10.2020 г.

\section{REFERENCES}

Vainshtein, S. I. (1991) Mir kochevnikov tsentra Azii [The world of nomads of the center of Asia]. Moscow, Nauka. 296 p. (In Russ.).

Dashibalov, B. B. and Rassadin, V. I. (2004) Otkuda vyshli predki mongolov? [Where did the ancestors of the Mongols come from?]. Vostochnaia kollektsiia, Zima, no. 4 (19), pp. 34-41. (In Russ.).

Dashibalov, B. B. (2005) Na mongolo-tiurkskom pogranich'e (Etnokul'turnye protsessy v Iugo-Vostochnoi Sibiri v srednie veka) [On the Mongol-Turkic border: Ethnocultural processes in South-Eastern Siberia in the Middle ages]. Ulan-Ude, Izd-vo BNTs SO RAN. 202 p. (In Russ.).

Dushan, U. D. (1973) Istoriko-etnograficheskie zametki ob Erketenevskom uluse Kalmytskoi ASSR [Historical and ethnographic notes on ulus Erlenescar, Kalmyk ASSR]. In: Etnograficheskie vesti, no. 3. / ed. by N. Sh. Tashninov. Elista, Kalmytskii NIIIaLI. 229 p. Pp. 31-107. (In Russ.).

Kalmyki [The Kalmyks] (2010). Ed. by E. P. Bakaeva and N. L. Zhukovskaya. Moscow, Nauka. 568 p. (In Russ.).

Kalmytskie bogatyrskie skazki = Khal'mg baatrlg tuul's [The Kalmyk heroic tales] (2017) / prep., transl. by B. B. Mandzhieva, T. A. Mikhaleva and Ts. B. Seleeva. Moscow, Kalmytskii nauch. tsentr RAN. 560 p. (In Russ. and Kalm.).

Kalmytskie skazki [Kalmyk fairy tales] (1962a) / ed. by I. K. Ilishkin and U. U. Ochirov. Elista, Kalmgosizdat. 331 p. (In Russ.).

Kalmytskie skazki [Kalmyk fairy tales] (1962b) / comp. by B. Dzhibinov. Elista, Kalmgosizdat. 183 p. (In Russ.).

Kalmytskie skazki [Kalmyk fairy tales] (1978) / transl. from Kalm. Elista, Kalm. kn. izd-vo. 148 p. (In Russ.).

Kalmytsko-russkii slovar' [Kalmyk-Russian Dictionary] (1977) / ed. by B. D. Muniea. Moscow, Russkii yazyk Publ. 764 p. (In Russ.).

Kornievskii, V. N. (2017) Kalmyki Donskoi oblasti, Astrakhanskoi i Stavropol'skoi gubernii [Kalmyks of the Don region, Astrakhan and Stavropol governorates]. Elista, KalmNTs RAN. 85 p. (In Russ.).

Kyzlasov, L. R. (1992) Ocherki po istorii Sibiri i Tsentral'noi Azii [Essays on the history of Siberia and Central Asia]. Krasnoiarsk, Izd-vo Krasnoiarskogo universiteta. 224 p. (In Russ.).

Nebol'sin, P. I. (1852) Ocherki byta kalmykov Khoshoutovskogo ulusa [Essays on the life of the Kalmyks in Khoshoutovsky ulus]. St. Petersburg, Tip. K. Kraiia. 192 p. (In Russ.).

Nekliudov, S. Yu. (1988) Oirat-kalmytskaia mifologiia [Oirat-Kalmyk mythology]. In: Mify narodov mira [Myths of the peoples of the world]: in 2 vol. / ed. by S. A. Tokarev. Moscow, Sovetskaia entsiklopediia. Vol. 2. 671 p. Pp. 247-248. (In Russ.).

Ondar, A. U. (2018) Sistema pitaniia tuvintsev-todzhintsev [The diet of Tozhu Tuvans] In: Aktual'nye problemy issledovaniia etnoekologicheskikh i etnokul'turnykh traditsii narodov Saiano-Altaia [Urgent issues of research in ethnoecological and ethnocultural traditions of the Sayan-Altai peoples]. Materials of the V-th international scientific and practical conference of young scientists, postgraduates and students / ed. by U. V. Ondar. Kyzyl, Tuvinskii gosuniversitet. 235 p. Pp. 12-15. (In Russ.).

Ostrovskikh, P. E. (1898) Kratkii otchet o poezdke v Todzhinskii khoshun Uriankhaiskoi zemli [Brief report on a trip to the Tozhu khoshun of Uriankhai territory]. Izvestiia IRGO, vol. XXXIV. Issue IV. Pp. 424-432. (In Russ.).

Pallas, P. S. (1773) Puteshestvie po raznym provintsiyam Rossiiskoi imperii [A journey through various provinces of the Russian Empire] : in 3 vols. St. Petersburg, Imperatorskaya Akademiya Nauk. Vol. 1. 455 p. (In Russ.).

Potanin, G. N. (1881) Ocherki Severo-Khapadnoi Mongolii [Essays On Northwestern Mongolia]. Vol. 2. Materialy etnograficheskie [Ethnographic materials]. St. Petersburg, Tip. V. Kirshbauma. 182, 87 p. (In Russ.). 
Potapov, L. P. (1953) Ocherki po istorii altaitsev [Essays on the history of the Altai people]. Moscow, Leningrad, Izd-vo AN SSSR. 445 p. (In Russ.).

Potapov, L. P. (1969) Ocherki narodnogo byta tuvintsev [The Tuvans: sketches of the folk lifestyle and related household activities]. Moscow, Nauka, GRVL. 402 p. (In Russ.).

Prokof'eva, E. D. (2011) Protsess natsional' noi konsolidatsii tuvintsev [The Process of National Consolidation of the Tuvans]. St. Petersburg, Nauka. 538 p. (In Russ.).

Sanchirov, V. P. (2003) O material'noi kul'ture oiratov XIII-XVII vekov [On the material culture of the Oirats in the $13^{\text {th }}-17^{\text {th }}$ centuries]. Mongolovedenie, no. 2 (1), pp. 203-210. (In Russ.).

Sem' zvezd: kalmytskie legendy i predaniia [Seven stars: Kalmyk legends and traditions] (2007) / comp. by D. E. Basaev. $2^{\text {nd }}$ ed. Elista, Kalm. kn. izd-vo. 415 p. (In Russ.).

Skazki i predaniia altaiskikh tuvintsev [Fairy tales and legends of the Altaian Tuvans] (1994). Comp. by E. Taube. Moscow, Vostochnaya Literatura. 410 p. (In Russ.).

Skazki narodov Sibiri [Tales of the peoples of Siberia] (1984) / transl. by A. L. Garf et al. Novosibirsk, Zapadno-Sibirskoe knizhnoe izdatel'stvo. 43 p. (In Russ.).

Tuvinskie geroicheskie skazaniya [Tuvan heroic tales] (1997) / comp. by S. M. Orus-ool. Novosibirsk, Nauka. 584 p. (In Russ.)

Tuvinskie narodnye skazki [Tuvan folk tales] (1988) / retelling and processing by M. Khadakhane. Moscow, Detskaia literatura. 111 p. (In Russ.).

Tuvinskie narodnye skazki [Tuvan folk tales] (1994a) / comp. by Z. B. Samdan. Novosibirsk, Nauka. 460 p. (In Russ.).

Tuvinskie narodnye skazki [Tuvan folk tales] (1994b). Ed. by V. M. Gatsak. Novosibirsk, Nauka. 460 p. (In Russ.).

Khal'mg tuul's [Kalmyk fairy tales] (1974) / Bart beldsn' B. B. Okonov, E. D. Muchkinova. Elista, KNIIIaLI. 4-gch bot'. 274 p. (In Kalm.).

Sharaeva, T. I. (2019) «I otkuda Vashi svaty?» (realii i mental'nye obrazy prostranstva v svadebnom obriade kalmykov) ['So where are your in-laws from?': Realities and mental images within the space of Kalmyk wedding rites)]. New Research of Tuva, no. 3, pp. 135-148. (In Russ.). DOI: https://www.doi.org/10.25178/nit.2019.3.11

Sharaeva, T. I. and Aiyzhy, E. V. (2019) Chai v traditsionnoi kul'ture kalmykov i tuvintsev [Tea in the traditional culture of the Kalmyks and Tuvans]. New Research of Tuva, no. 4, pp. 140-153. (In Russ.). DOI: https://www.doi.org/10.25178/ nit.2019.4.12

Erdniev, U. E. (1970) Kalmyki (konets XIX - nachalo XX v.): istoriko-etnografieskie ocherki [Kalmyks (late $19^{\text {th }}-$ early $20^{\text {th }}$ centuries): historical and ethnographic essays]. Elista, Kalmizdat. 307 p. (In Russ.).

Submission date: 12.10.2020. 